\title{
In Vitro Antioxidative Activity and Antihypertensive Activity of Soy Sauce Cake Derived from the Manufacturing of Japanese Style Fermented Soy Sauce
}

\author{
Takeshi Nagai $^{1,2 *}$, Yasuhiro Tanoue ${ }^{3}$, Norihisa $\mathrm{Kai}^{3}$, Nobutaka Suzuki ${ }^{4}$ \\ ${ }^{1}$ Graduate School of Agriculture Sciences, Yamagata University, Yamagata, Japan; ${ }^{2}$ Graduate School, Prince of Songkla University, \\ Songkhla, Thailand; ${ }^{3}$ National Fisheries University, Yamaguchi, Japan; ${ }^{4}$ Nagoya Research Institute, Aichi, Japan. \\ Email: ${ }^{*}$ tnagai@tds1.tr.yamagata-u.ac.jp,nandemofreefree@yahoo.co.jp
}

Received April 25 ${ }^{\text {th }}, 2012$; revised July $3^{\text {rd }}, 2012$; accepted July $10^{\text {th }}, 2012$

\begin{abstract}
As the manufacture of soy sauce produces a large quantity of soy sauce cake as one of food processing waste, it is necessary to search for possible ways for their utilization. Chemical composition of soy sauce cake was analyzed to use as a material of high-value functional ingredients. The results showed that soy sauce cake could be potentially used as functional ingredients rich in proteins, with high antioxidative activitiy, free radical scavenging activity, and antihypertensive activity. Based on their $\mathrm{IC}_{50}$ values, the hydrolysates from soy sauce cake were more significantly effective against superoxide anion radicals and ACE, compared with hydroxyl radicals and DPPH radicals. The present study indicates that a large amount of soy sauce cake can be used as source of proteins with good antioxidative activity, free radical scavenging activity, and antihypertensive activity. The utilization of soy sauce cake may be also to contribute to reduce food processing wastes and to resolve an environmental problem.
\end{abstract}

Keywords: Soy Sauce Cake; Food Processing Waste; Utilization; Antioxidative Activity; Scavenging Activity; Antihypertensive Activity

\section{Introduction}

Wheat is one of the three major grains in the world, and the annual production is around six hundred million tons worldwide in 2008 [1]. Soybean is called as the five grains containing wheat, rice, beans, millet ( $a w a$ and kibi) in Japan. These crops are considered as the most important materials of plant foods. Soy sauce is the brown and salty flavoring produced during the enzymatic hydrolysis of soybean proteins into amino acids and small peptides to make it more flavorful. Soy sauce has been integrated into the traditional cuisines of many East Asian and Southeast Asian cultures. Soy sauce is widely used as a particularly important flavoring in Thai, Chinese, Korean, and Japanese cuisines. Despite their rather similar appearance, soy sauce produced in different cultures and regions are different in taste, consistency, fragrance, and saltiness. Soy sauce is called by many names such as toyo in the Philippines, kecap in Indonesia, jiangyou or chiyou in China, Joseon ganjang in Korea, and shoyu in Japan. Traditional soy sauce is made by mixing soybeans and grain with cultures such as Aspergillus oryzae and other related microorganisms and yeasts. The mixture

"Corresponding author. was then fermented naturally in giant urns and under the sun, which was to contribute additional flavours. At present, the mixture is generally placed in a temperature and humidity controlled incubation chamber. In Japan, soy sauce manufacture is composed of six stages, namely, preparation of starter, treatment of raw materials, koji making, mash making and aging, pressing, and refining. The annual production of soy sauce is about 200,000 kiloliters worldwide in 2007 [2]. In Japan the annual production of it is about 900,000 kiloliters in 2008 [2]. The main soy sauce varieties in Japan are koikuchi, usukuchi, tamari, shiro, and saishikomi. In particular, over $80 \%$ of the Japanese domestic soy sauce production is of koikuchi, and can be considered the typical Japanese soy sauce. It is produced from an equal quantity of soybean and wheat. Then soy sauce cake as wastes comes to produce about $10 \%-20 \%$ (about 110,000 tons per year) against the quantity of production of soy sauce in the manufacturing process. These contain a large amount of bioactive substances such as amino acids, proteins, dietary fibers, and isoflavones. So, it has been desired the development of the effective utilization of soy sauce cake. However, most of these cakes are still disposed as an industrial waste, although a part of these cakes is used as 
fertilizers, animal foods and feeds, papermaking, and soil conditioners. Japan Livestock Industry Association [3] reported the quantities of plant food processing wastes in Japan were as follows: brewer's grain (about one million tons), soybean cake (tofu refuse; about seven hundred thousand tons), whisky cake (about three hundred thousand tons), juice extraction cake from orange, apple, and grape (about eleven hundred thousand tons), soy sauce cake (about nine hundred thousand tons), and so on. There are also many kinds of food processing wastes such as used tea leaves, coffee lees, shochu distillery by-product, sake lees, and rice bran. Among these wastes, the nutritional value of soy sauce cake is significantly high to remain many proteins, lipids, fibers, and beneficial isoflavones after manufacturing process of soy sauce [4]. So soy sauce cake is considered as a good protein source having high energy. Moreover, in comparison with other by-products it was reported that it could be store at $10^{\circ} \mathrm{C}$ or $30^{\circ} \mathrm{C}$ for 28 days without decomposition to contain highly concentration of $\mathrm{NaCl}$ [5].

Reactive oxygen species (ROS) such as the superoxide anion radical, hydroxyl radical, singlet oxygen, and hydrogen peroxide are known to generated both by normal cellular metabolism and by exogenous factors, including smoking and air pollution [6]. Oxidative stress is caused by an imbalance between the generation of ROS and the activity of the body's antioxidant defenses. Severe oxidative stress damages proteins, lipids, carbohydrates, and DNA [7] and causes accelerated aging as well as chronic diseases such as cancer and heart disease. Scavengers of these ROS may be used as a preventive tool to control oxidative stress-related diseases. Many kinds of natural compounds have shown antioxidant activity against different kinds of ROS [8]. Among them, plant foods contain many different classes and types of antioxidants, knowledge of their total antioxidant capacity, which is the cumulative capacity of food components to scavenge ROS, would be useful for human consumption and nutritional supplementation [9]. The present research explores in vitro antioxidative activity and antihypertensive activity of soy sauce cake as one of food processing waste to apply in food processing and biomedical fields and to reduce food processing wastes.

\section{Materials and Methods}

\subsection{Materials}

Raw soybean and whole wheat flour, salt, and koji mold for soy sauce were purchased from a local wholesale market, Hokkaido, Japan and used in this study. Pepsin from porcine stomach mucosa (EC 3.4.23.1; 2× crystallized; $3085 \mathrm{U} / \mathrm{mg}$ protein) was from Sigma, USA. ACE from bovine lung (1 U), 2,2'-azobis(2-amidinopropane) dihydrochloride (AAPH), bovine serum albumin (BSA), $\alpha$-chymotrypsin from bovine pancreas (EC 3.4.21.1; 1000 usp chymotrypsin units/mg), 2-deoxy-D-ribose, ethylenediaminetetraacetic acid disodium salt (EDTA), 1,1-diphenyl-2-picrylhydrazyl (DPPH), ethyl acetate for spectrochemical analysis grade, hippuryl-L-histidyl-Lleucine as substrate peptide, linoleic acid, nitroblue tetrazolium salt (NBT), papain (EC 3.4.22.2; digestive powder; 1:350), thermolysin from Bacillus thermoprotealyticus Rokko (EC 3.4.24.4; $7000 \mathrm{PU} / \mathrm{mg}$ ), $\alpha$-tocopherol, trypsin from porcine pancreas crystallized (EC 3.4.21.4; 4500 USP trypsin U/mg protein), and xanthine were from Wako Chemicals Co. Ltd. (Osaka, Japan). Pronase E from Streptomyces griseus $(1,000,000$ tyrosine $\mathrm{U} / \mathrm{g}$ ) was from Kaken Pharmaceutical Co. Ltd. (Tokyo, Japan). Xanthine oxidase from butter milk (XOD; 0.33 $\mathrm{U} / \mathrm{mg}$ powder) was from Oriental Yeast Co. Ltd. (Tokyo, Japan). All other reagents were of analytical grade.

\subsection{Manufacturing of Soy Sauce}

Seven hundred grams of soybeans are soaked in running water overnight to hydrate the beans. To denature the protein for enzyme digestion, the beans were cooked by steaming under atmospheric pressure. The same grams of whole wheat flour was roasted in order to be digested by mold amylase. The cooked soybeans and the roasted flour are mixed prior to inoculation with the starter, koji mold. After the materials were cooled by hand mixing, the mixture of soybeans and wheat was inoculated with $0.2 \%$ of koji mold. The mixed materials were cultured in clean and flat plastic pail. After 18 - $24 \mathrm{~h}$, the materials were cooled down by hand mixing and transferred the inoculated mixture in small wooden boxes. Next, to produce more protease, the temperature of the mixture was kept below $37^{\circ} \mathrm{C}$. After $18-24 \mathrm{~h}$, the materials were cooled down by hand mixing. The incubation temperature was maintained at $28^{\circ} \mathrm{C}-30^{\circ} \mathrm{C}$, and then the mixture was cultured continuously. The mixture should be cultured for a total of $72 \mathrm{~h}$. The harvested soybean-wheat koji (shoyu koji) was placed into appropriate fermentation container. About $22 \%$ salt solution was poured and mixed into the shoyu koji. The mixture, moromi was allowed to undergo hydrolysis for 6 months with occasional agitation. The aged mash was filtered under a high hydraulic pressure through cloth. The clear liquid was heated at $80^{\circ} \mathrm{C}$ for $10 \mathrm{~min}$, and then the pasteurized product was stored in semi-closed tank to allow the coagulum produced during heating to settle. The soy sauce produced was then bottled and sealed. The soybean cake was collected to analyze the chemical composition. The remained pressed cake (soy sauce cake) was dried using dryer at $40^{\circ} \mathrm{C}$ and the dried matters were stored in deoxi- 
dizer at $-20^{\circ} \mathrm{C}$ until used.

\subsection{Preparation of Water Extract and Enzymatic Hydrolysates from Soy Sauce Cake}

\subsubsection{Water Extraction}

Dried matters were suspended and extracted with 20 volumes of distilled water with shaking at $20^{\circ} \mathrm{C}$ for $48 \mathrm{~h}$. The extracts were centrifuged at $30,000 \times \mathrm{g}$ for $30 \mathrm{~min}$, and the supernatants were pooled, and then lyophilized.

\subsubsection{Pepsin Digestion}

Dried matters were added and homogenized with 20 volumes of distilled water, and $\mathrm{pH}$ of the suspension was adjusted at 2.0 using $\mathrm{HCl}$. The digestion was started by adding $1.0 \%(\mathrm{w} / \mathrm{w})$ pepsin. After $48 \mathrm{~h}$ at $37^{\circ} \mathrm{C}$, hydrolysis was stopped by boiling for $10 \mathrm{~min}$. The hydrolysate was centrifuged at $30,000 \times \mathrm{g}$ for $30 \mathrm{~min}$ to remove the residue. The supernatants were pooled, and then lyophilized.

\subsubsection{Trypsin Digestion}

Dried matters were added and homogenized with 20 volumes of distilled water, and $\mathrm{pH}$ of the suspension was adjusted at 7.6 using $\mathrm{NaOH}$. The homogenates were digested with $1.0 \%(\mathrm{w} / \mathrm{w})$ trypsin. After $48 \mathrm{~h}$ at $37^{\circ} \mathrm{C}$, hydrolysate was boiled for $10 \mathrm{~min}$ to inactive the enzyme. This was centrifuged at $30,000 \times \mathrm{g}$ for $30 \mathrm{~min}$, and the supernatants were pooled and lyophilized.

\subsubsection{Papain Digestion}

Dried matters were added and homogenized with 20 volumes of distilled water, and $\mathrm{pH}$ of the suspension was adjusted at 7.0 using $\mathrm{NaOH}$. The homogenates were digested with $1.0 \%(\mathrm{w} / \mathrm{w})$ papain at $37^{\circ} \mathrm{C}$ for $48 \mathrm{~h}$. The hydrolysate was stopped by boiling for $10 \mathrm{~min}$. The hydrolysate was centrifuged at $30,000 \times \mathrm{g}$ for $30 \mathrm{~min}$ to remove the residue. The supernatants were pooled and lyophilized.

\subsubsection{Chymotrypsin Digestion}

Dried matters were added and homogenized with 20 volumes of distilled water, and $\mathrm{pH}$ of the suspension was adjusted at 7.9 using $\mathrm{NaOH}$. The homogenates were digested with $1.0 \%(\mathrm{w} / \mathrm{w})$ chymotrypsin at $37^{\circ} \mathrm{C}$ for $48 \mathrm{~h}$. The enzyme reaction was stopped by boiling for $10 \mathrm{~min}$. The hydrolysate was centrifuged at $30,000 \times \mathrm{g}$ for $30 \mathrm{~min}$, and the supernatants were pooled, and then lyophilized.

\subsubsection{Pronase E Digestion}

Dried matters were added and homogenized with 20 volumes of distilled water, and $\mathrm{pH}$ of the suspension was adjusted at 7.0 using $\mathrm{NaOH}$. The homogenates were di- gested with $1.0 \%(\mathrm{w} / \mathrm{w})$ pronase $\mathrm{E}$ at $37^{\circ} \mathrm{C}$ for $48 \mathrm{~h}$. The hydrolysate was stopped by boiling for $10 \mathrm{~min}$. The hydrolysate was centrifuged at $30,000 \times \mathrm{g}$ for $30 \mathrm{~min}$, and the supernatants were pooled, and then lyophilized.

\subsubsection{Thermolysin Digestion}

Dried matters were added and homogenized with 20 volumes of distilled water, and $\mathrm{pH}$ of the suspension was adjusted at 7.5 using $\mathrm{NaOH}$. The digestion was started by adding $0.1 \%(\mathrm{w} / \mathrm{w})$ thermolysin. After $48 \mathrm{~h}$ at $37^{\circ} \mathrm{C}$, hydrolysis was stopped by boiling for $10 \mathrm{~min}$. The hydrolysate was centrifuged at $30,000 \times \mathrm{g}$ for $30 \mathrm{~min}$ to remove the residue. The supernatants were pooled, and then lyophilized.

The lyophilized powders were used as the sample solution $\left(1,10\right.$, and $\left.100 \mathrm{mg} / \mathrm{ml} \mathrm{H}_{2} \mathrm{O}\right)$ for the following tests.

\subsection{Chemical Analysis}

AOAC methods were used as chemical analysis of soy sauce cake [10]. Moisture content was measured using a hot oven. Protein content was determined by the Kjeldahl method using a conversion factor of 6.25. Lipid content was analyzed by ether extraction. Ash content was determined using a furnance. Crude fiber content was estimated by the Prosky method. Salt content was measured by the Mohr method. The protein concentration in water extract and enzymatic hydrolysates from soy sauce cake were measured by the method of Lowry et al. [11] using BSA as standard.

\subsection{Antioxidative Activity}

Antioxidative activities of water extract and enzymatic hydrolysates from soy sauce cake were measured in a linoleic acid oxidation system described by Nagai et al [12]. A $0.083 \mathrm{ml}$ of sample solution and $0.208 \mathrm{ml}$ of 0.2 $\mathrm{M}$ sodium phosphate buffer ( $\mathrm{pH} 7.0)$ were mixed with $0.208 \mathrm{ml}$ of $2.5 \%(\mathrm{w} / \mathrm{v})$ linoleic acid in ethanol. The preoxidation was initiated by the addition of $20.8 \mu \mathrm{l}$ of $0.1 \mathrm{M} \mathrm{AAPH}$ and carried out at $37^{\circ} \mathrm{C}$ for $200 \mathrm{~min}$ in the dark. The degree of oxidation was measured according to the thiocyanate method for measuring peroxides by reading the absorbance at $500 \mathrm{~nm}$ after colouring with $\mathrm{FeCl}_{2}$ and ammonium thiocyanate. Ascorbic acid (1 and $5 \mathrm{mM})$ and $\alpha$-tocopherol $(1 \mathrm{mM})$ were used as positive control. Distilled water was used as negative control.

\subsection{Effect of Superoxide Anion Radical}

Effect of superoxide anion radical was evaluated as described by Nagai et al. [12]. This system contained 0.48 $\mathrm{ml}$ of $0.05 \mathrm{M}$ sodium carbonate buffer ( $\mathrm{pH} 10.5), 0.02 \mathrm{ml}$ 
of $0.15 \%$ of BSA, $0.02 \mathrm{ml}$ of $3 \mathrm{mM}$ EDTA, $0.02 \mathrm{ml}$ of $0.75 \mathrm{mM}$ NBT, $0.02 \mathrm{ml}$ of $3 \mathrm{mM}$ xanthine, and $0.02 \mathrm{ml}$ of sample solution. After preincubation at $25^{\circ} \mathrm{C}$ for 10 min, the reaction was started by adding $6 \mathrm{mU}$ XOD and carried out at $25^{\circ} \mathrm{C}$ for $20 \mathrm{~min}$. The reaction was stopped by adding $0.02 \mathrm{ml}$ of $6 \mathrm{mM} \mathrm{CuCl}$. The solution was centrifuged at $12,000 \mathrm{rpm}$ for $5 \mathrm{~min}$, and the absorbance of the supernatants were measured at $560 \mathrm{~nm}$ and the scavenging activity was calculated by measuring the amount of formazan that was reduced from NBT by superoxide. Ascorbic acid ( 1 and $5 \mathrm{mM})$ and $\alpha$-tocopherol $(1 \mathrm{mM})$ were used as positive control. Distilled water was used as negative control. The $\mathrm{IC}_{50}$ value was defined as the concentration of the sample required to inhibit $50 \%$ of superoxide anion radical activity.

\subsection{Effect of Hydroxyl Radical}

The effect of hydroxyl radical in water extract and enzymatic hydrolysates from soy sauce cake was assayed using the deoxyribose method [12]. The reaction mixture contained $0.45 \mathrm{ml}$ of $0.2 \mathrm{M}$ sodium phosphate buffer $(\mathrm{pH}$ 7.0), $0.15 \mathrm{ml}$ of $10 \mathrm{mM}$ 2-deoxy-D-ribose, $0.15 \mathrm{ml}$ of 10 $\mathrm{mM} \mathrm{FeSO}$-EDTA, $0.525 \mathrm{ml}$ of distilled water, and 0.075 $\mathrm{ml}$ of sample solution in an Eppendorf tube. The reaction was started by the addition of $0.15 \mathrm{ml}$ of $10 \mathrm{mM} \mathrm{H}_{2} \mathrm{O}_{2}$. After incubation at $37^{\circ} \mathrm{C}$ for $4 \mathrm{~h}$, the reaction was stopped by adding $0.75 \mathrm{ml}$ of $1.0 \%(\mathrm{w} / \mathrm{v})$ of 2-thiobarbituric acid in $50 \mathrm{mM} \mathrm{NaOH}$ and $0.75 \mathrm{ml}$ of $2.8 \%(\mathrm{w} / \mathrm{v})$ trichloroacetic acid. The solution was boiled for $10 \mathrm{~min}$, and then cooled in water. The solution was centrifuged at 12,000 rpm for $5 \mathrm{~min}$, and the absorbance of the supernatants was measured at $520 \mathrm{~nm}$. Hydroxyl radical scavenging activity was evaluated as the inhibition rate of 2-deoxyD-ribose oxidation by hydroxyl radicals. Ascorbic acid (1 and $5 \mathrm{mM})$ and $\alpha$-tocopherol $(1 \mathrm{mM})$ were used as positive control. Distilled water was used as negative control. The $\mathrm{IC}_{50}$ value was defined as the concentration of the sample required to inhibit $50 \%$ of hydroxyl radical activity.

\subsection{Effect of DPPH Radical}

The effect of DPPH radical was measured as described by Nagai et al. [12]. The assay mixtute contained $0.03 \mathrm{ml}$ of $1.0 \mathrm{mM}$ of DPPH radical solution in ethanol, $0.24 \mathrm{ml}$ of $99 \%$ of ethanol, and $0.03 \mathrm{ml}$ of sample solution. The mixture was rapidly mixed and after 30 min the absorbance of the solution was measured at $517 \mathrm{~nm}$. Ascorbic acid $(0.1$ and $1.0 \mathrm{mM})$ and $\alpha$-tocopherol $(1 \mathrm{mM})$ were used as positive control. Distilled water was used as negative control. The $\mathrm{IC}_{50}$ value was defined as the concentration of the sample required to inhibit $50 \%$ of DPPH radical activity.

\subsection{ACE Inhibitory Activity}

The ACE inhibitory activities of water extract and enzymatic hydrolysates from soy sauce cake were performed as described by Nagai et al. [12]. Twenty five microliters of sample solution and $75 \mu \mathrm{l}$ of $0.1 \mathrm{M}$ sodium borate buffer ( $\mathrm{pH}$ 8.3) containing $5.83 \mathrm{mM}$ hippuryl-L-histidylL-leucine as substrate and $1.0 \mathrm{M} \mathrm{NaCl}$ in an Eppendorf tube were preincubated at $37^{\circ} \mathrm{C}$ for $5 \mathrm{~min}$. The mixture was incubated with $25 \mu \mathrm{l}$ of $0.1 \mathrm{M}$ sodium borate buffer (pH 8.3) containing $1 \mathrm{mU} \mathrm{ACE}$ and $1.0 \mathrm{M} \mathrm{NaCl}$ at $37^{\circ} \mathrm{C}$ for $60 \mathrm{~min}$. After the reaction was stopped by the addition of $125 \mu \mathrm{l}$ of $1.0 \mathrm{M} \mathrm{HCl}$, the resulting hippuric acid was extracted with $750 \mu \mathrm{l}$ of ethyl acetate by violently mixing for $15 \mathrm{~s}$. After centrifugation at $6000 \mathrm{rpm}$ for 3 min, $500 \mu \mathrm{l}$ of the upper layer was transported into the other tube and evaporated at $80^{\circ} \mathrm{C}$ for $2 \mathrm{~h}$. The hippuric acid was dissolved in $500 \mu \mathrm{l}$ of distilled water, and then the absorbance was measured at $228 \mathrm{~nm}$. The $\mathrm{IC}_{50}$ value was defined as the concentration of the sample required to inhibit $50 \%$ of the ACE activity.

\subsection{Statistical Analysis}

Each assay was repeated 3 times independently and the results were reported as means \pm standards deviation. Statistical analysis was performed by using Student's $t$-test.

\section{Results and Discussion}

Chemical composition of soy sauce cake was analyzed using AOAC method [10]. As a result, the contents of water, proteins, lipids, carbohydrates, and ash were $38.2 \%, 14.8 \%, 7.0 \%, 32.2 \%$, and $7.8 \%$, respectively (Table 1). The contents of crude fibers were $27.2 \%$, that is, the contents of sugars were $5.0 \%$. Moreover, the content of $\mathrm{NaCl}$ was high about $5.6 \%$. Ito et al. [13] reported the

Table 1. Chemical parameters of soy sauce cake.

\begin{tabular}{cc}
\hline Sample & Parameters \\
\hline Water & $38.2 \pm 0.4(\%)$ \\
Proteins & $14.8 \pm 0.3(\%)$ \\
Lipids & $7.0 \pm 0.2(\%)$ \\
Carbohydrates & $32.2 \pm 0.4(\%)$ \\
Fibers & $27.2 \pm 0.4(\%)$ \\
Ash & $7.8 \pm 0.3(\%)$ \\
Salt content & $5.6 \pm 0.2(\%)$ \\
Specific gravity & $1.052 \pm 0.03$ \\
pH & $5.4 \pm 0.1$ \\
\hline
\end{tabular}


chemical composition of soy sauce cake prepared from defatted soybean. These contents were as follows: 37.5 (water), 24.3 (proteins), 6.9 (lipids), 25.0 (crude fibers), and $1.6 \%$ (ash except for $\mathrm{NaCl}$ ), respectively. Hori et al. [5] studied the characteristics of component as feed of by-products derived from food industry. As a result, they reported the composition of soy sauce cake used in the study was as follows: 34.7 (water), 19.6 (proteins), 5.6 (lipids), 6.2 (fibers), and 6.8\% (ash), respectively. Saito et al. [14] studied the utilization of fermentation food processing waste such as juice extraction cake from grape, rice bran, sake lees, and soy sauce cake. They reported the chemical composition of soy sauce cake was as follows: 37.6 (water), 7.8 (proteins), 7.2 (lipids), 38.9 (carbohydrates), and $8.5 \%$ (ash), respectively. In general, soy sauce cake contains water (about 30\%) and salt (about $6 \%-10 \%$ ). However, the results from these reports were different each other: the reason is due to the difference of compression equipments of the aged mash (moromi). On the other hand, specific gravity and $\mathrm{pH}$ of soy sauce cake were 1.052 and $5.4\left(20^{\circ} \mathrm{C}\right)$, respectively (Table 1).

The water extract and enzymatic hydrolysates using six proteases such as pepsin, trypsin, papain, chymotrypsin, pronase E, and thermolysin from soy sauce cake were successfully prepared. The yields of the hydrolysates were high, ranging from $22.7 \%$ to $29.9 \%$ on the basis of dry matter (Table 2). The protein contents $\mu \mathrm{g} / \mathrm{mg}$ in lyophilized powder ranged from 356.3 to 414.9 on the basis of dry matter (Table 2). It was proved that soy sauce cake was a good protein source to obtain the peptide by analysis of its protein content.

The antioxidative activities of water extract and enzymatic hydrolysates from soy sauce cake were investigated in vitro. For $1 \mathrm{mg} / \mathrm{ml}$ water extract the activity was very low similar to that of negative control (Table 3). Each enzymatic hydrolysate showed twice activity as high as water extract. It suggested that many species of

Table 2. The yields and protein contents of water extract and enzymatic hydrolysates from soy sauce cake.

\begin{tabular}{ccc} 
Sample & Yield $(\%)$ & $\begin{array}{c}\text { Total protein } \\
(\mu \mathrm{g} / \mathrm{mg} \text { sample powder })\end{array}$ \\
\hline Water extract & $25.4 \pm 0.9$ & $389.5 \pm 4.6$ \\
Pepsin digestion & $27.3 \pm 1.0$ & $371.7 \pm 3.9$ \\
Trypsin digestion & $28.9 \pm 0.8$ & $402.1 \pm 4.2$ \\
Papain digestion & $22.7 \pm 0.7$ & $356.3 \pm 3.7$ \\
Chymotrypsin digestion & $29.9 \pm 1.0$ & $414.9 \pm 4.5$ \\
Pronase digestion & $28.5 \pm 0.9$ & $388.3 \pm 4.0$ \\
Thermolysin digestion & $29.5 \pm 1.0$ & $400.6 \pm 4.1$ \\
\hline
\end{tabular}

Table 3. Antioxidative activities of water extract and enzymatic hydrolysates from soy sauce cake.

\begin{tabular}{|c|c|c|c|}
\hline \multirow{2}{*}{ Sample (mg/ml) } & \multicolumn{3}{|c|}{$\begin{array}{l}\text { Absorbance }(500 \mathrm{~nm}) \\
\text { Time }(\mathrm{min})\end{array}$} \\
\hline & 50 & 100 & 200 \\
\hline \multicolumn{4}{|l|}{ Water extract } \\
\hline 1 & $0.234 \pm 0.019$ & $0.549 \pm 0.027$ & $1.261 \pm 0.033$ \\
\hline 10 & $0.072 \pm 0.004$ & $0.160 \pm 0.005$ & $0.349 \pm 0.007$ \\
\hline 100 & $0.019 \pm 0.002$ & $0.037 \pm 0.003$ & $0.050 \pm 0.003$ \\
\hline
\end{tabular}

Pepsin digestion

$\begin{array}{cccc}1 & 0.174 \pm 0.006 & 0.292 \pm 0.020 & 0.623 \pm 0.023 \\ 10 & 0.062 \pm 0.003 & 0.093 \pm 0.008 & 0.197 \pm 0.016 \\ 100 & 0.000 & 0.000 & 0.000\end{array}$

Trypsin digestion

$\begin{array}{cccc}1 & 0.120 \pm 0.005 & 0.252 \pm 0.011 & 0.600 \pm 0.019 \\ 10 & 0.032 \pm 0.003 & 0.068 \pm 0.003 & 0.116 \pm 0.003 \\ 100 & 0.000 & 0.005 \pm 0.001 & 0.000\end{array}$

Papain digestion

$\begin{array}{cccc}1 & 0.198 \pm 0.008 & 0.375 \pm 0.006 & 0.751 \pm 0.024 \\ 10 & 0.068 \pm 0.003 & 0.138 \pm 0.004 & 0.210 \pm 0.009 \\ 100 & 0.019 \pm 0.002 & 0.031 \pm 0.002 & 0.052 \pm 0.002\end{array}$

Chymotryspin digestion

$\begin{array}{cccc}1 & 0.136 \pm 0.004 & 0.285 \pm 0.019 & 0.617 \pm 0.020 \\ 10 & 0.045 \pm 0.003 & 0.071 \pm 0.004 & 0.182 \pm 0.007 \\ 100 & 0.000 & 0.009 \pm 0.001 & 0.013 \pm 0.001\end{array}$

Pronase E digestion

$\begin{array}{cccc}1 & 0.153 \pm 0.005 & 0.284 \pm 0.020 & 0.516 \pm 0.018 \\ 10 & 0.045 \pm 0.002 & 0.079 \pm 0.004 & 0.170 \pm 0.006 \\ 100 & 0.000 & 0.000 & 0.002\end{array}$

Thermolysin digestion

\begin{tabular}{cccc}
1 & $0.142 \pm 0.004$ & $0.236 \pm 0.010$ & $0.514 \pm 0.015$ \\
10 & $0.028 \pm 0.002$ & $0.055 \pm 0.005$ & $0.091 \pm 0.007$ \\
100 & 0.000 & 0.000 & 0.001 \\
Ascorbic Acid $(1 \mathrm{mM})$ & $0.022 \pm 0.001$ & $0.135 \pm 0.006$ & $0.469 \pm 0.027$ \\
Ascorbic acid (5 mM) & $0.016 \pm 0.001$ & $0.032 \pm 0.003$ & $0.090 \pm 0.008$ \\
$\alpha$-Tocopherol (1mM) & 0.006 & $0.025 \pm 0.001$ & $0.028 \pm 0.002$ \\
Control & $0.379 \pm 0.008$ & $0.715 \pm 0.025$ & $1.406 \pm 0.041$ \\
\hline
\end{tabular}


peptides showed the antioxidative activity to hydrolyze the proteins using enzymes. The activities for $10 \mathrm{mg} / \mathrm{ml}$ trypsin and thermolysin hydrolysates were similar to that of $5 \mathrm{mM}$ ascorbic acid. Except for water extract, each enzymatic hydrolysate exhibited high levels of activity. On the other hand, $100 \mathrm{mg} / \mathrm{ml}$ sample solution had extremely high antioxidative activity similar or higher activitiy than $1 \mathrm{mM} \alpha$-tocopherol. Particularly, pepsin, trypsin, pronase $\mathrm{E}$, and thermolysin hydrolysates completely inhibited linoleic acid oxidation. The antioxidative activities of these samples increased with increasing the concentration of sample.

Superoxide anion radical scavenging activities of water extract and enzymatic hydrolysates from soy sauce cake were measured using xanthine/xanthine oxidase system. The activities tended to increase with an increasing degree of the concentration of sample (Table 4). The activities for $1 \mathrm{mg} / \mathrm{ml}$ water extract and trypsin, chymotrypsin, pronase $\mathrm{E}$, and thermolysin hydrolysates were higher than that of $1 \mathrm{mM}$ ascorbic acid, although the activity of pepsin hydrolysate was low about only $7 \%$. For $10 \mathrm{mg} / \mathrm{ml}$ trypsin hydrolysate the activity was high and was similar to that of $1 \mathrm{mM} \alpha$-tocopherol, although the activities of other sample species did not amount to that of $1 \mathrm{mM} \alpha$-tocopherol. On the contrary, the activities for $100 \mathrm{mg} / \mathrm{ml}$ sample species were remarkable high above $86 \%$, except for papain hydrolysate (about $52 \%$ ). Particularly, pepsin hydrolysate completely scavenged the radicals (Table 4).

Hydroxyl radical scavenging activities of water extract and enzymatic hydrolysates from soy sauce cake were investigated and compared with those of ascorbic acid and $\alpha$-tocopherol as positive controls. All sample species had scavenging activities on hydroxyl radicals, and the activities increased with increasing the concentration of sample species (Table 4). Except for water extract and trypsin hydrolysate, the activities of enzymatic hydrolysates for $1 \mathrm{mg} / \mathrm{ml}$ were similar or higher than that of 1 $\mathrm{mM}$ ascorbic acid. The activities for $10 \mathrm{mg} / \mathrm{ml}$ enzymatic hydrolysates were equal or twice as high as that of $5 \mathrm{mM}$ ascorbic acid. Moreover, these scavenging rates for 100 $\mathrm{mg} / \mathrm{ml}$ reached about $58 \%$ to $64 \%$, although the activities did not slightly amount to that $1 \mathrm{mM} \alpha$-tocopherol.

DPPH radical scavenging activities of water extract and enzymatic hydrolysates from soy sauce cake were measured. As a result, the activities for $1 \mathrm{mg} / \mathrm{ml} \mathrm{sample}$ species were low about 3\%-8\% similar or higher than that of $0.1 \mathrm{mM}$ ascorbic acid (Table 4). With increasing the sample concentration the activities increased and 10 $\mathrm{mg} / \mathrm{ml}$ sample species scavenged its radical about $17 \%$ $24 \%$. These activities did not amount to that of $1 \mathrm{mM}$ ascorbic acid. For $100 \mathrm{mg} / \mathrm{ml}$ the activity of trypsin hydrolysate was highest about $70 \%$ among these sample
Table 4. Superoxide anion radical, hydroxyl radical, and DPPH radical scavenging activities of water extract and enzymatic hydrolysates from soy sauce cake.

\begin{tabular}{cccc}
\hline \multirow{2}{*}{ Sample $(\mathrm{mg} / \mathrm{ml})$} & \multicolumn{3}{c}{ Scavenging activity $(500 \mathrm{~nm})$} \\
\cline { 2 - 4 } & $\begin{array}{c}\text { Superoxide } \\
\text { anion radical }\end{array}$ & $\begin{array}{c}\text { Hydroxyl } \\
\text { radical }\end{array}$ & $\begin{array}{c}\text { DPPH } \\
\text { radical }\end{array}$ \\
\hline Water extract & & & \\
1 & $20.4 \pm 0.41$ & $6.5 \pm 0.04$ & $2.6 \pm 0.02$ \\
10 & $27.1 \pm 0.52$ & $14.6 \pm 0.24$ & $18.9 \pm 0.37$ \\
100 & $86.3 \pm 5.01$ & $62.7 \pm 4.23$ & $54.7 \pm 4.12$ \\
Pepsin digestion & & & \\
1 & $6.5 \pm 0.03$ & $13.7 \pm 0.21$ & $5.9 \pm 0.03$ \\
10 & $45.4 \pm 3.21$ & $19.7 \pm 0.40$ & $21.5 \pm 0.45$ \\
100 & $>100$ & $61.8 \pm 4.01$ & $61.3 \pm 3.99$
\end{tabular}

Trypsin digestion
1

10

100

Papain digestion$$
1
$$

10

100

Chymotryspin

digestion$$
1
$$

10

100

Pronase E digestion

$$
1
$$

10

100

Thermolysin digestion

$\begin{array}{cccc}1 & 19.6 \pm 0.42 & 15.6 \pm 0.34 & 8.0 \pm 0.12 \\ 10 & 43.2 \pm 2.98 & 33.5 \pm 3.11 & 22.6 \pm 0.38 \\ 100 & 95.7 \pm 3.89 & 61.8 \pm 3.25 & 59.5 \pm 3.38 \\ \text { Ascorbic acid (1 mM) } & 14.7 \pm 0.20 & 13.2 \pm 0.21 & 3.1 \pm 0.04^{*} \\ \text { Ascorbic acid (5 mM) } & 89.9 \pm 5.31 & 17.6 \pm 0.71 & 34.1 \pm 2.01^{* *} \\ \alpha \text {-Tocopherol }(1 \mathrm{mM}) & 52.6 \pm 4.18 & 67.6 \pm 4.34 & 87.6 \pm 2.75\end{array}$

$5.5 \pm 0.03$

$14.9 \pm 0.25$

$52.8 \pm 3.96$
$0.1 \mathrm{mM}$ ascorbic acid; ${ }^{* *} 1.0 \mathrm{mM}$ ascorbic acid. 
species tested, although the activity did not reach that of $1 \mathrm{mM} \alpha$-tocopherol. Other sample species for $100 \mathrm{mg} / \mathrm{ml}$ quenched DPPH radicals about 53\% - 61\%.

Antihypertensive activites of water extract and enzymatic hydrolysates from soy sauce cake were determined and are shown in Table 5. These sample species except for trypsin hydrolysate had no activities. For $10 \mathrm{mg} / \mathrm{ml}$ water extract and these hydrolysates had a moderate inhibitory activities about $36 \%-59 \%$. On the other hand, $100 \mathrm{mg} / \mathrm{ml}$ sample species possessed extremely high activities, about $84 \%$ - 98\% (Table 5). The pronase E hydrolysate almost perfectly inhibited ACE activity. It suggested that ACE inhibitory activities of hydrolysates from soy sauce cake derived from the manufacturing of soy sauce were correlated with the amino acid composition and its sequences of the proteins in these hydrolysates. From these results, it was obvious that a large quan- tity of peptides possessing high ACE inhibitory activity could be obtain from soy sauce cake.

The $\mathrm{IC}_{50}$ values of water extract and enzymatic hydrolysates from soy sauce cake against superoxide anion radical activities were calculated. As a result, its values ranged from 38.3 to $93.6 \mathrm{mg} / \mathrm{ml}[50.1 \mathrm{mg} / \mathrm{ml}$ (water extract), $41.3 \mathrm{mg} / \mathrm{ml}$ (pepsin hydrolysate), $38.3 \mathrm{mg} / \mathrm{ml}$ (trypsin hydrolysate), $93.6 \mathrm{mg} / \mathrm{ml}$ (papain hydrolysate), $46.1 \mathrm{mg} / \mathrm{ml}$ (chymotrypsin hydrolysate), $38.4 \mathrm{mg} / \mathrm{ml}$ (pronase E hydrolysate), and $40.7 \mathrm{mg} / \mathrm{ml}$ (thermolysin hydrolysate), respectively] (Figure 1).

The $\mathrm{IC}_{50}$ values of water extract and these hydrolysates from against hydroxyl radical activities were calculated. As a result, its values were around $80 \mathrm{mg} / \mathrm{ml}[77.5 \mathrm{mg} / \mathrm{ml}$ (water extract), $76.8 \mathrm{mg} / \mathrm{ml}$ (pepsin hydrolysate), 81.8 $\mathrm{mg} / \mathrm{ml}$ (trypsin hydrolysate), $82.7 \mathrm{mg} / \mathrm{ml}$ (papain hydrolysate), $79.4 \mathrm{mg} / \mathrm{ml}$ (chymotrypsin hydrolysate), 71.0 $\mathrm{mg} / \mathrm{ml}$ (pronase E hydrolysate), and $73.4 \mathrm{mg} / \mathrm{ml}$ (thermolysin hydrolysate), respectively] (Figure 1).

The $\mathrm{IC}_{50}$ values of water extract and these hydrolysates against DPPH radical activities were calculated. As a result, its values ranged from 66.6 to $93.2 \mathrm{mg} / \mathrm{ml}$ [89.0 $\mathrm{mg} / \mathrm{ml}$ (water extract), $78.0 \mathrm{mg} / \mathrm{ml}$ (pepsin hydrolysate), $66.6 \mathrm{mg} / \mathrm{ml}$ (trypsin hydrolysate), $93.2 \mathrm{mg} / \mathrm{ml}$ (papain hydrolysate), $86.8 \mathrm{mg} / \mathrm{ml}$ (chymotrypsin hydrolysate), $82.6 \mathrm{mg} / \mathrm{ml}$ (pronase E hydrolysate), and $80.1 \mathrm{mg} / \mathrm{ml}$ (thermolysin hydrolysate), respectively] (Figure 1).

Moreover, the $\mathrm{IC}_{50}$ values of water extract and these hydrolysates against ACE activity were calculated. As a result, its values ranged from 38.5 to $52.8 \mathrm{mg} / \mathrm{ml}[51.5$ $\mathrm{mg} / \mathrm{ml}$ (water extract), $52.8 \mathrm{mg} / \mathrm{ml}$ (pepsin hydrolysate), $38.5 \mathrm{mg} / \mathrm{ml}$ (trypsin hydrolysate), $51.8 \mathrm{mg} / \mathrm{ml}$ (papain hydrolysate), $50.7 \mathrm{mg} / \mathrm{ml}$ (chymotrypsin hydrolysate), $41.8 \mathrm{mg} / \mathrm{ml}$ (pronase E hydrolysate), and $43.0 \mathrm{mg} / \mathrm{ml}$ (thermolysin hydrolysate), respectively] (Figure 1). Okamoto et al. [15] reported that various fermented foods
Table 5. ACE inhibitory activities of water extract and enzymatic hydrolysates from soy sauce cake.

\begin{tabular}{|c|c|c|}
\hline Sample (mg/ml) & Activity (\%) & $\mathrm{IC}_{50}(\mathrm{mg}$ protein $/ \mathrm{ml})$ \\
\hline Water extract & & $20.4 \pm 0.4$ \\
\hline 1 & 0.0 & \\
\hline 10 & $35.8 \pm 2.2$ & \\
\hline 100 & $87.4 \pm 4.9$ & \\
\hline Pepsin digestion & & $19.6 \pm 0.3$ \\
\hline 1 & 0.5 & \\
\hline 10 & $39.1 \pm 2.5$ & \\
\hline 100 & $83.9 \pm 4.4$ & \\
\hline Trypsin digestion & & $15.5 \pm 0.2$ \\
\hline 1 & $8.2 \pm 0.3$ & \\
\hline 10 & $59.1 \pm 3.2$ & \\
\hline 100 & $97.5 \pm 4.9$ & \\
\hline Papain digestion & & $18.5 \pm 0.2$ \\
\hline 1 & 0.0 & \\
\hline 10 & $40.1 \pm 2.4$ & \\
\hline 100 & $85.3 \pm 4.3$ & \\
\hline Chymotryspin digestion & & $21.0 \pm 0.3$ \\
\hline 1 & 0.0 & \\
\hline 10 & $47.8 \pm 2.8$ & \\
\hline 100 & $84.0 \pm 4.1$ & \\
\hline Pronase E digestion & & $16.2 \pm 0.2$ \\
\hline 1 & 0.0 & \\
\hline 10 & $50.2 \pm 2.9$ & \\
\hline 100 & $99.4 \pm 5.1$ & \\
\hline Thermolysin digestion & & $17.2 \pm 0.2$ \\
\hline 1 & 0.0 & \\
\hline 10 & $58.3 \pm 3.0$ & \\
\hline 100 & $92.6 \pm 4.9$ & \\
\hline
\end{tabular}

possessed high ACE inhibitory activities as $\mathrm{IC}_{50}$ values as follows: sake (general, junmai, ginjo, and genmai 3.77 $6.85 \mathrm{mg} / \mathrm{ml})$, fish sauce from salmon, sardine, and anchovy (1.35 - $3.15 \mathrm{mg} / \mathrm{ml})$, soy sauce (koikuchi, usukuchi, saishikomi, shiro, and tamari $0.71-17.8 \mathrm{mg} / \mathrm{ml}$ ), old style mirin $(85.6 \mathrm{mg} / \mathrm{ml}$ ), vinegar (several crops and rice $9.84-10.1 \mathrm{mg} / \mathrm{ml}$ ), miso (barley, and soybean 2.38 $5.35 \mathrm{mg} / \mathrm{ml}$ ), cheese (camembert, blue, and red cheddar $0.16-0.27 \mathrm{mg} / \mathrm{ml})$, natto from soybean $(0.19 \mathrm{mg} / \mathrm{ml})$, 


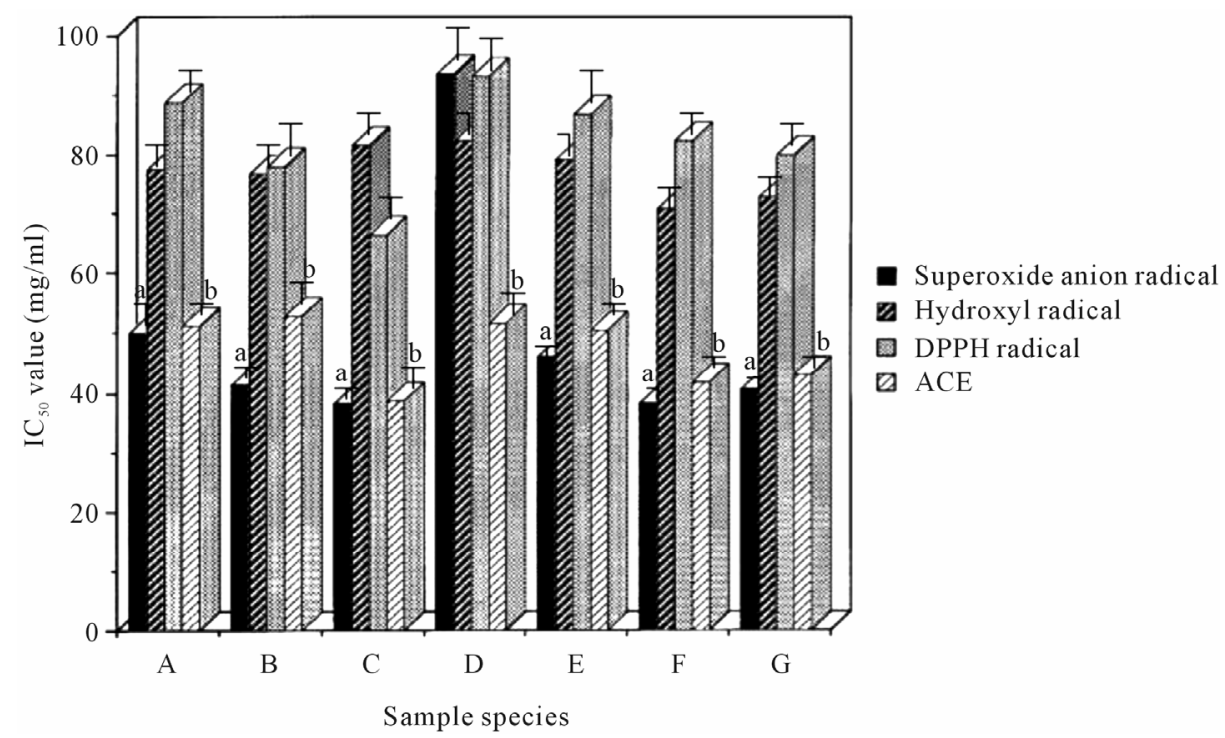

Figure 1. The $\mathrm{IC}_{50}$ values of water extract and enzymatic hydrolysates from soy sauce cake against superoxide anion radicals, hydroxyl radicals, DPPH radicals, and ACE. (A) Water extract; (B) Pepsin hydrolysate; (C) Trypsin hydrolysate; (D) Papain hydrolysate; (E) Chymotrypsin hydrolysate; (F) Pronase E hydrolysate; (G) Thermolysin hydrolysate. Each value in this figure is the mean \pm SD $(n=3)$. (a) $P<0.05$, compared with hydroxyl radicals and DPPH radicals; (b) $P<0.05$, compared with hydroxyl radicals and DPPH radicals.

nyufu from soybean $(0.66 \mathrm{mg} / \mathrm{ml})$, and temphe from soybean $(0.51 \mathrm{mg} / \mathrm{ml})$, respectively. These fermented foods as the Maillard reaction products showed high ACE inhibitory activities.

Next, the relationship between these $\mathrm{IC}_{50}$ values of water extract and enzymatic hydrolysates from soy sauce cake and these radicals and ACE was investigated. Based on their $\mathrm{IC}_{50}$ values, the hydrolysates from soy sauce cake were more significantly effective against superoxide anion radicals and ACE, compared with hydroxyl radicals and DPPH radicals. That is to say, it was suggested that water extract and enzymatic hydrolysates from soy sauce cake had highly scavenging and inhibitory effects against superoxide anion radicals and ACE, but lower against DPPH radicals.

Antioxidant compounds play an important role as health-protective factors. Most of the antioxidant compounds in a typical diet derive from plant sources and belong to various classes of compounds with a wide variety of physical and chemical properties [16]. They can delay or inhibit lipid oxidation by inhibiting the initiation or propagation of oxidizing chain reactions and are involved in scavenging free radicals [17-21]. Our present study showed that a large amount of proteins possessed in enzymatic hydrolysates prepared from soy sauce cake. These hydrolysates exhibited highly antioxidative activity and scavenging activities against superoxide anion radicals, hydroxyl radicals, and DPPH radicals. In addition, these hydrolysates possessed high ACE inhibitory activity. In general, food proteins taking in the body are first digested in stomach by pepsin, and then the hydrolysates further digested in intestines by trypsin, chymotrypsin, and carboxyl protease. It is expected the higher antioxidative activity, scavenging activities against free radicals, and ACE inhibitory activity in enzymatic hydrolysates from soy sauce cake derived from the manufacturing of soy sauce until these hydrolysates are absorbed in the body system, although it is necessary to decrease the quantity of $\mathrm{NaCl}$.

Soybeans are recognized as being a good source of several nutrients that contain many kinds of polyphenols as isoflavone analogues such as daidzin and genistin [22]. It is well known that these isoflavones show antioxidative activities in fermented soybean products as natto, tempeh, miso, shoyu, etc. Esaki et al. [23] reported that these isoflavones were hydrolyzed into the corresponding aglycones, daidzein and genistein by $\beta$-glucosidase from soybeans. They clarified that these free isoflavones possessed antioxidative activities in soybean pastes in the antioxidative assay using liposome prepared from egg yolk lecithin [23]. They also isolated potent antioxidative isoflavones, 8-hydroxydaidzein (8-OHD) and 8-hydroxygenistein $(8-\mathrm{OHG})$ that have an $o$-dihydroxy structure between the 7- and 8-position from daidzein and genistein by a hydroxylation reaction during the fermentation process with Aspergillus saitoi $[24,25]$ and A. oryzae [26-28]. Moreover, they studied about these free isoflavones such as 8-OHD and 8-OHG in the soy sauce cake obtained from several brewing makers [29]. As a result, it found that the remaining rate of these $o$-dihydroxy- 
isoflavones (ODI) in various soy sauce cake were very high, and that the antioxidative ODI were potent in rich enough amounts to utilize these cakes as antioxidative materials. The extracted preparations with ethanol and ethyl acetate exhibited strong antioxidative effects against a fish oil in both oil and liquid/aqueous system. Moreover, these also showed higher DPPH radical scavenging activities and stronger inhibition of lipid peroxidation in a liposome system. It is suggested from the present study that a large amount of soy sauce cake can be used as an underutilized resource with these functionalities for different applications in food processing and biomedical fields. The use of soy sauce cake may be also to contribute to reduce food processing wastes and to resolve an environmental problem. Further research will be necessary to confirm the principal antioxidants and ACE inhibitors in water extract and enzymatic hydrolysates from soy sauce cake to contain the functional compounds such as isoflavones, phenolcarboxylic-acids and these derivatives, and melanoidin (browning reaction product).

\section{REFERENCES}

[1] FAO Statistics, 2008. http://faostat.fao.org/default.aspx

[2] Soysauce Information Center, 2012. http://www.soysauce.or.jp/arekore/index.html

[3] Japan Livestock Industry Association, 2012. http://jlia.lin.gr.jp/

[4] M. Hori, "Development of Animal Feeds Using ByProducts Derived from Food Industry," Oita Industrial Research Institure News, Vol. 151, 2009, pp. 3-4.

[5] M. Hori, N. Hida, M. Tokuda and A. Kashima, "Research of Characteristic of Component as Feed of By-Products Derived from Food Industry," Journal of Oita Industrial Research Instiutute, Vol. 22, 1997, pp. 34-40.

[6] B. Halliwell, R. Aeschbach, J. Löliger and O. I. Aruoma, "The Characterization of Antioxidants," Food and Chemical Toxicology, Vol. 33, No. 7, 1995, pp. 601-617. doi:10.1016/0278-6915(95)00024-V

[7] W. Droge, "Free Radicals in the Physiological Control of Cell Function," Physiological Reviews, Vol. 82, No. 1, 2001, pp. 47-95.

[8] P. G. Pieta, "Flavonoid as Antioxidants," Journal of Natural Products, Vol. 63, 2000, pp. 1035-1042. doi:10.1021/np9904509

[9] N. Pellegrini, M. Serafini, B. Colombi, D. Del Rio, S. Salvatore, M. Bianchi and F. Brighenti, "Total Antioxidant Capacity of Plant Foods, Beverages and Oils Consumed in Italy Assessed by Three Different in Vitro Assays," Journal of Nutrition, Vol. 33, 2003, pp. 28122819.

[10] AOAC, "Official Methods of Analysis of AOAC International," 18th Edition, Association of Official Analytical Chemists, Arlington, 2005.
[11] O. H. Lowry, N. J. Rosebrough, A. L. Farr and R. J. Randall, "Protein Measurement with the Folin Phenol Reagent," The Journal of Biological Chemistry, Vol. 193, No. 1, 1951, pp. 265-275.

[12] T. Nagai and T. Nagashima, "Functional Properties of Dioscorin, a Soluble Viscous Protein from Japanese Yam (Dioscorea opposita Thunb.) Tuber Mucilage tororo," Zeitschrift für Naturforschung, Vol. 61c, 2006, pp. 792798.

[13] Y. Ito, C. Narishima, Y. Yonekura, H. Sakurai, Y. Arakawa and J. Ohsawa, "Utilization of Soy Sauce Cake (Syoyu-Kasu)-Application for 'Tsukemono'," Journal of Iwate Industrial Research Institute, Vol. 5, 1998, pp. 208212.

[14] M. Saito, T. Hashimoto, M. Kojima, K. Naganuma, H. Kimura, K. Ago and T. Mori, "Utilization of Fermentation Food Processing Waste (1st Report)," Journal of Yamanashi Prefectural Industrial Technology, Vol. 24, 2010, pp. 143-147.

[15] A. Okamoto, H. Hanagata, E. Matsumoto, Y. Yawamura, Y. Koizumi and F. Yanagida, "Angiotensin I-Converting Enzyme Inhibitory Activities of Various Fermented Foods," Bioscience, Biotechnology, and Biochemistry, Vol. 59, No. 6, 1995, pp. 1147-1149. doi:10.1271/bbb.59.1147

[16] K. Apel and H. Hirt, "Reactive Oxygen Species: Metabolism, Oxidative Stress, and Signal Transduction," Annual Review of Plant Biology, Vol. 55, 2004, pp. 373-399. doi:10.1146/annurev.arplant.55.031903.141701

[17] A. Arora, R. Sairam and G. Srivastava, "Oxidative Stress and Antioxidative System in Plants," Current Science, Vol. 82, No. 10, 2002, pp. 1227-1238.

[18] A. Boots, G. Haenen and A. Bast, "Health Effects of Quercetin: From Antioxidant to Nutraceutical," European Journal of Pharmacology, Vol. 585, No. 2-3, 2008, pp. 325-337. doi:10.1016/j.ejphar.2008.03.008

[19] I. Moeller, P. Jensen and A. Hansson, "Oxidative Modifications to Cellular Components in Plants," Annual Review of Plant Biology, Vol. 58, 2007, pp. 459-481. doi:10.1146/annurev.arplant.58.032806.103946

[20] B. Romier, Y. J. Schneider, Y. Larondelle and A. During, "Dietary Polyphenols Can Modulate the Intestinal Inflammatory Response," Nutrtion Reviews, Vol. 67, No. 7, 2009, pp. 363-378. doi:10.1111/j.1753-4887.2009.00210.x

[21] P. Singh and G. K. Goyal, "Dietary Lycopene: Its Properties and Anticarcinogenic Effects," Comprehensive Reviews in Food Science and Food Safety, Vol. 7, No. 3, 2008, pp. 255-270. doi:10.1111/j.1541-4337.2008.00044.x

[22] K. Okubo, "DMF (Dry Mouth Feel, Undesirable) Components of Soybeans and Behavior of the Components on Soybean Food Processing," Nippon Shokuhin Kogyo Gakkaishi, Vol. 35, 1998, pp. 866-874. doi:10.3136/nskkk1962.35.12 866

[23] H. Esaki, S. Kawakishi, T. Inoue and T. Osawa, "Potent Antioxidative $o$-Dihydroxyisoflavones in Soybean Pastes 
and Their Antioxidative Activities," Nippon Shokuhin Kagaku Kogaku Kaishi, Vol. 48, 2001, pp. 51-57. doi:10.3136/nskkk.48.51

[24] H. Esaki, H. Onozaki, Y. Morimitsu, S. Kawakishi and T. Osawa, "Potent Antioxidative Isoflavones Isolated from Soybeans Fermented with Aspergillus saitoi," Bioscience, Biotechnology, and Biochemistry, Vol. 62, No. 4, 1998, pp. 740-746. doi:10.1271/bbb.62.740

[25] H. Esaki, R. Watanabe, H. Onozaki, S. Kawakishi and T. Osawa, "Formation Mechanism for Potent Antioxidative $o$-Dihydroxyisoflavones in Soybeans Fermented with Aspergillus saitoi," Bioscience, Biotechnology, and Biochemistry, Vol. 63, No. 5, 1999, pp. 851-858. doi:10.1271/bbb.63.851

[26] H. Esaki, S. Kawakishi, Y. Morimitsu and T. Osawa, "New Potent Antioxidative $o$-Dihydroxyisoflavones in Fermented Japanese Soybean Products," Bioscience, Bio- technology, and Biochemistry, Vol. 63, No. 5, 1999, pp. 1637-1639. doi:10.1271/bbb.63.1637

[27] H. Esaki, R. Watanabe, H. Masuda, T. Osawa and S. Kawakishi, "Formation and Changes of $o$-Dihydroxyisoflavones during Production of Soybean Pastes," Nippon Shokuhin Kagaku Kogaku Kaishi, Vol. 48, 2001, pp. 189-195. doi:10.3136/nskkk.48.189

[28] H. Esaki, T. Osawa and S. Kawakishi, "Potent Antioxidative $o$-Dihydroxyisoflavones in Soy Sauces and Their Antioxidative Activities," Nippon Shokuhin Kagaku Kogaku Kaishi, Vol. 49, 2002, pp. 476-483. doi:10.3136/nskkk.49.476

[29] H. Esaki, R. Watanabe, N. Hishikawa, T. Osawa and S. Kawakishi, "Utility of Isoflavone Preparations from Soy Sauce Cake as Antioxidant Materials," Nippon Shokuhin Kagaku Kogaku Kaishi, Vol. 51, 2004, pp. 47-53. doi:10.3136/nskkk.51.47 